\title{
Castillo v. Castillo: \\ Limitation Periods and The Conflict of Laws
}

\section{GERALD ROBERTSON*}

A motor vehicle accident occurs in California, involving residents of Alberta. The resulting lawsuit is commenced in Alberta two years less a day later. Whose limitation period applies - Alberta (two years) or California (one year)? The answer is "both," according to the recent decision of Rawlins J. in Castillo v. Castillo.' The purpose of this case comment is to argue that the decision is wrong.

Castillo is important because it is the first case ${ }^{2}$ to deal with the relationship between s. 12 of the Limitations $\mathrm{Act}^{3}$ and the Supreme Court of Canada decision in Tolofson v. Jensen. ${ }^{4}$ In Tolofson the Supreme Court held that actions in tort are governed by the law of the place where the tort occurs (lex loci delicti), except for procedural aspects which are governed by the law of the place where the action is brought (lex fori). Significantly, however, the Supreme Court also held that limitation periods are substantive rather than procedural, and hence governed by the lex loci delicti. $^{5}$

Tolofson was decided in 1994. In 1996 Alberta's new Limitations Act was enacted (and proclaimed in 1999). Section 12 of the Act provides that:

The limitations law of the Province shall be applied whenever a remedial order is sought in this Province, notwithstanding that, in accordance with conflict of law rules, the claim will be adjudicated under the substantive law of another jurisdiction.

Were it not for s. 12, the outcome of Castillo would have been straightforward: Tolofson dictates that limitation periods are substantive and hence governed by the lex loci delicti (California) rather than the lex fori (Alberta). Therefore, the action would have been time-barred because of California's one-year limitation period. However, s. 12 complicates the issue. Is its effect (and purpose) to reverse Tolofson and apply Alberta limitation periods?

Justice Rawlins held that the combination of s. 12 and Tolofson requires a "two step approach," as follows:

Professor, Faculty of Law, University of Alberta.

[2002] A.J. No. 519 (Q.B.), online: QL (AJ) [hereinafter Castillo].

An earlier case - Dipalma v. Smart (2000), 90 Alta. L.R. (3d) 171 (Q.B.), online: QL (AJ) held that $s .12$ of the Limitations $A c t$ is not retroactive, but the decision does not expressly deal with the meaning of s. 12. At the same time, however, the issue of retroactivity would have been entirely moot if the court had adopted Rawlins J.'s reasoning with respect to the effect of s. 12.

R.S.A. 2000 , c. L- 12 .

[1994] 3 S.C.R. 1022 [hereinafter Tolofson].

For a detailed discussion of the Tolofson decision see J-G. Castel \& J. Walker, Canadian Conflict of Laws. 5th ed. (Toronto: Butterworths, 2002) at 6.7-6.8 and 35.8-35.20. 
The analysis involves a two step approach. Firstly, the Court must determine if there is a cause of action under Califormia law, including California limitation law; i.e. could the action have been brought under that regime, including any limitation that foreign jurisdiction prescribes. If that question is affirmative and only in that case, does the Court proceed to the second step of the analysis, that is, the Court determines pursuant to Section 12 of the Limitations Act, whether the action is brought within Alberta limitations. In this case, if the limitation to bring this action in California was less than 2 years (i.e., 1 year) the Plaintiff's claim is statute barred there and there is no need to consider Section 12 of the Limitations Act of Alberta. The Applicant's application to dismiss would be allowed. ${ }^{6}$

The effect of this decision is to give defendants the benefit of both limitation periods. If the action is time-barred under the lex loci delicti (in this case, California), the action is dismissed because it does not meet the Tolofson test. On the other hand, even if the action is not time-barred under the lex loci delicti, if it is time-barred under Alberta law (as the lex fori) the action is still dismissed because of s. 12 of the Limitations Act. For example, if in Castillo the California limitation period had been three years and the action had been commenced after $21 / 2$ years, it would still have been time-barred (according to Rawlins J.'sreasoning) because Alberta'stwo-year limitation period would have applied by virtue of s. 12. In other words, the defendant gets the best of both worlds: the action is dismissed if it is time-barred under either the law of Alberta or the lex loci delicti. ${ }^{?}$

The problem with the Castillo decision is that it is entirely inconsistent with the wording and purpose of s. 12 of the Limitations Act. On its face the meaning of s. 12 seems reasonably clear: to reverse the effect of Tolofson by making Alberta limitation periods applicable regardless of whether the other aspects of the claim are governed by the lex loci delicti. Despite the apparent sophistication of Rawlins J.'s "two step approach," the net result of her decision is simple: the action was dismissed by applying California's one-year limitation law. That, with respect, seems completely contrary to the language of s. 12, which dictates that the court shall apply the limitation law of Alberta. Clearly, in Castillo, Alberta's two-year limitation period was not applied.

The decision is also inconsistent with the underlying purpose of s. 12. Alberta's new Limitations Act was the product of a report published by the Alberta Law Reform Institute in $1989 .{ }^{8}$ That report is unequivocal that the Institute viewed the issue as a choice between applying the limitations law of either the lex fori or the lex loci delicti, but certainly not both. ${ }^{9}$ This is especially apparent from the Institute's discussion of the policy reasons underlying that choice, and in particular the following:

Courts should apply local procedural law. Limitations law is based on a foundation of legal philosophy and concepts of fairness. Applying the limitations law of Alberta ensures the application of a just

6astillo, supra note 1 at para. 11.

7 A similar view, which supports the conclusion reached by Rawlins J., is expressed in G.K. Randall, "The New Limitations Act: Traps for the Unwary," in Legal Education Society of Alberta, 32nd Annual Banf Refresher Course: Civil Litigation (1999) at Tab 22.

Alberta Law Reform Institute, Limilations (Report No. 55, 1989).

The same is true of the earlier Report for Discussion, Alberta Law Reform Institute, Limitations (Report for Discussion No. 4. 1986) at 240-52. 
limitations system in accordance with accepted Alberta principles because the Alberta law reflects what Alberta believes is the fairest balance between the conflicting interests of claimants and defendants. ${ }^{10}$

Justice Rawlins responded to this by pointing out that the Institute's report predated Tolofson and that, in her opinion, "The Report's recommendation concerning Section 12 was based on policy considerations which have now been superseded by the Supreme Court in Tolofson." "That may be so, but it overlooks the fact that $s .12$ was enacted two years after Tolofson. One must presume that the Alberta Legislature had been well aware of the Supreme Court's decision in Tolofson when it voted to enact $\mathrm{S}$. 12. Indeed, the underlying policy objective of s. 12 is evident from the debates on Bill 205 in the Legislative Assembly. ${ }^{12}$ During the debate by the Committee of the Whole, the sponsor of the Bill (the Honourable Denis Herard) stated as follows:

\begin{abstract}
Mr. Chairman, the final issue that I wish to comment on is conflict of laws. To clarify, conflict of laws occurs in situations where the law of more than one jurisdiction can apply. The legal rules that have been developed to determine which law applies when and where are called conflict of laws rules. Generally, the law relating to a procedure before the court is governed by the jurisdiction where the matter is heard. Substantive laws that apply to the substance of an issue are governed by other rules, and sometimes that can be the law of another jurisdiction. To remove the often difficult task of categorizing limitations legislation to determine whose law applies to a claim, Bill 205 states that, regardless, limitations law is governed by Alberta law if an action is brought in this province. ${ }^{13}$
\end{abstract}

Based on that stated legislative objective (and the wording of the statute itself), the underlying purpose of s. 12 is clear: to apply Alberta's limitations law, and only Alberta's limitations law, even where the tort occurs elsewhere.

One curious feature of Rawlins J.'s decision is that it makes no mention of counsel's position or submissions with respect to her "two step approach." The judgment contains numerous references to counsel's submissions on a number of other issues, but none of these relate to the actual basis of the decision. One is left with the impression that Rawlins J.'s reasons may have come as something of a surprise to counsel on both sides.

In summary, Rawlins J.'s "two step approach" merely clouds the real issue and effect of the decision, namely, that it allows the defendant to take the benefit of the limitation periods in both jurisdictions. That result flies in the face of the language of s. 12 of the Limitations Act and is contrary to the stated legislative objective of the section. Above all, the reasoning in Castillo fails to address the basic question of what possible policy objectives are served by applying the limitation periods of both jurisdictions.

12 It is now well established that a court is entitled to look at Hansard in interpreting legislation: see R. v. Gisby (2000), 271 A.R. 303 (C.A.). It is interesting to note that in D.J.N. v. Director of Child Welfare (1999), 248 A.R. 159 (Q.B.) Rawlins J. quoted extensively from Hansard in coming to her decision. 